\title{
Acoustic Emission of 3D Angle Interlock Glass Fibre Composites
}

Link to publication record in Manchester Research Explorer

\section{Citation for published version (APA):}

Gresil, M., Saleh, M., Arshad, M., Soutis, C., \& SOUTIS, C. (2015). Acoustic Emission of 3D Angle Interlock Glass Fibre Composites. In 10th International Workshop on Structural Health Monitoring

\section{Published in:}

10th International Workshop on Structural Health Monitoring

\section{Citing this paper}

Please note that where the full-text provided on Manchester Research Explorer is the Author Accepted Manuscript or Proof version this may differ from the final Published version. If citing, it is advised that you check and use the publisher's definitive version.

\section{General rights}

Copyright and moral rights for the publications made accessible in the Research Explorer are retained by the authors and/or other copyright owners and it is a condition of accessing publications that users recognise and abide by the legal requirements associated with these rights.

\section{Takedown policy}

If you believe that this document breaches copyright please refer to the University of Manchester's Takedown Procedures [http://man.ac.uk/04Y6Bo] or contact uml.scholarlycommunications@manchester.ac.uk providing relevant details, so we can investigate your claim.

\section{OPEN ACCESS}




\section{COVER SHEET}

Title: Acoustic Emission of 3D Angle Interlock Glass Fibre Composites

Authors: Matthieu Gresil

Mohamed Saleh

Mubeen Arshad

Constantinos Soutis

Proceedings of the $\mathbf{1 0}^{\text {th }}$ International Workshop on Structural Health Monitoring 2015 


\begin{abstract}
It is a big challenge to relate acoustic emission (AE) signal events to specific damage modes developed in composites under hygro-thermo-mechanical loading. This study provides further insight into the $\mathrm{AE}$ monitoring of a 3D angle interlock (AI) glass fibre composite and has revealed the complex nature of the relationship between the principal characteristics of recorded AE events on the one hand and the mechanical behaviour of the material on the other. Because the tested material here is transparent, the development of cracks can be observed in-situ during the test using optical images on the specimen. This paper presents experimental results on the use of $\mathrm{AE}$ on 3D AI glass fibre composites for structural health monitoring (SHM) of matrix cracks, during quasi-static tension of flat plates.
\end{abstract}

\title{
INTRODUCTION
}

Fibre-reinforced composite materials are used extensively in the aerospace industry because of their light weight, superior corrosion resistance and improved fatigue properties when compared to metals. However, the manufacturing costs, production rates and damage tolerance are current challenges faced by the composite industry. Three-dimensional (3D) woven composites have better through-thethickness properties in comparison to two-dimensional (2D) laminates; they show improved impact damage tolerance, high inter-laminar fracture toughness and reduced notch sensitivity. 3D fabrics were introduced to produce structural composites capable of withstanding multidirectional stresses.

Monitoring of acoustic emission (AE) during mechanical loading is an effective and widely used tool in the study of damage processes in glass fiber-reinforced composites. This study provides further insight into the AE monitoring of 3D AI glass fibre composites and has revealed the complex nature of the relationship between the principal characteristics of recorded AE events on the one hand and the mechanical behaviour of the material on the other.

Matthieu Gresil, School of Materials, University of Manchester, UK.

Mohamed Saleh, National Composites Certification and Evaluation Facility, University of Manchester, UK.

Mubeen Arshad, NCCEF, University of Manchester, UK.

Constantinos Soutis, Aerospace Research Institute, University of Manchester, UK. 
Tests were performed with piezoelectric wafer active sensors (PWAS) bonded on a tensile specimen acting as passive receivers of AE signals. The paper finishes with conclusions and suggestions for further work.

\section{DAMAGE MONITORED BY ACOUSTIC EMISSION}

The acoustic emission (AE) method allows the detection and location of damage using specific localisation algorithms. Knowledge of the propagation velocity and attenuation of the AE wave is required. However, contrary to metallic material, the anisotropic nature of composite material gives a large range of propagation velocity due to fibre orientation. Moreover, the attenuation of the AE waves is more complex than in a homogeneous material [1]. In addition, in a same composite material, wave attenuation is more significant in cracked than in healthy state, which will complicate the signal processing after few damage modes have developed, especially for the amplitude distribution. Qualifying damage started first in 2D composites and Mehan and Mullin in 1968 [2] managed to identify three basic failure mechanisms: (i) fiber fracture; (ii) matrix cracking; (iii) and fibre/matrix interfacial debonding. The authors reported the application of $\mathrm{AE}$ in composites in 1971 [3], discriminating audible types for these three basic damage modes using an AE system. After forty years, Godin et al. [4] conducted mapping of cross-ply glass/epoxy composites during tensile tests. They have classified four different acoustic signatures of failure and determined four conventional analyses of AE signals as depicted in Figure 1. Typical waveforms with A-Type (slow increase times at about 10-20 $\mu \mathrm{s}$ ) signals associated with matrix cracking, B-Type (sharp rising, lasted for $10 \mu \mathrm{s}$ and abruptly decreasing) with fibre/matrix interface de-bonding, C-Type associated with fibre failure, and D-Type (long rising times, high amplitudes, and very long durations) with delamination [4]. The most popular methods to identify damage are identification by signal amplitude distribution (signal strength) and by signal frequency. TABLE I and TABLE II show a comparison between the amplitude and the frequency distribution model that were encountered in the literature.
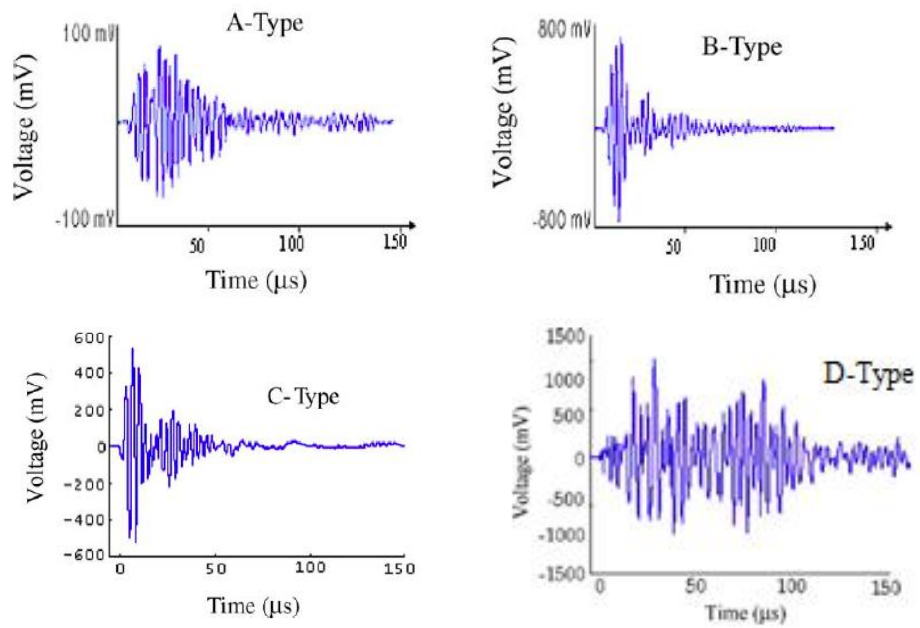

Figure 1: Typical waveforms collected during tensile tests on glass composite: A, B, C, D-types associated with matrix cracking, interface debonding, fibre failure, delamination, respectively [4]. 
TABLE I: AMPLITUDE DISTRIBUTION ACCORDING TO THE DAMAGE MECHANISM IN COMPOSITE MATERIALS.

\begin{tabular}{|c|c|c|c|c|}
\hline Ref. & $\begin{array}{c}\text { Matrix } \\
\text { cracking }\end{array}$ & $\begin{array}{c}\text { Interface decohesion } \\
\text { (fibre/matrix) }\end{array}$ & $\begin{array}{c}\text { Fibre/matrix friction and } \\
\text { fibres pull-out }\end{array}$ & $\begin{array}{c}\text { Fibres } \\
\text { breakage }\end{array}$ \\
\hline$[5]$ & $30-45 \mathrm{~dB}$ & $45-55 \mathrm{~dB}$ & -- & $>55 \mathrm{~dB}$ \\
\hline$[6]$ & $60-80 \mathrm{~dB}$ & $70-90 \mathrm{~dB}$ & -- & -- \\
\hline$[7]$ & $50 \mathrm{~dB}$ & -- & -- & -- \\
\hline$[8]$ & $40-70 \mathrm{~dB}$ & -- & -- & $60-100 \mathrm{~dB}$ \\
\hline$[9]$ & $40-55 \mathrm{~dB}$ & -- & $>80 \mathrm{~dB}$ & -- \\
\hline$[10]$ & $33-45 \mathrm{~dB}$ & $50-68 \mathrm{~dB}$ & $69-86 \mathrm{~dB}$ & $87-100 \mathrm{~dB}$ \\
\hline$[11]$ & $40-78 \mathrm{~dB}$ & $72-100 \mathrm{~dB}$ & -- & $95-100 \mathrm{~dB}$ \\
\hline$[12]$ & $40-55 \mathrm{~dB}$ & $60-65 \mathrm{~dB}$ & $65-85 \mathrm{~dB}$ & $85-95 \mathrm{~dB}$ \\
\hline$[4]$ & $35-80 \mathrm{~dB}$ & $50-80 \mathrm{~dB}$ & $70-100 \mathrm{~dB}$ & -- \\
\hline$[13]$ & $<70 \mathrm{~dB}$ & $<60 \mathrm{~dB}$ & -- & -- \\
\hline$[14]$ & $35-55 \mathrm{~dB}$ & $55-100 \mathrm{~dB}$ & -- & $35-80 \mathrm{~dB}$ \\
\hline$[15]$ & $40-60 \mathrm{~dB}$ & $50-70 \mathrm{~dB}$ & $80-100 \mathrm{~dB}$ & $80-100 \mathrm{~dB}$ \\
\hline
\end{tabular}

All of these studies show the difficulty of identifying damage modes for 2D composites and becomes more complicated for 3D woven composites. Only a small amount of studies has been reported for monitoring evolution of damage and ultimate failure in 3D woven composites. Li et al. [14] studied AE signals for 3D non-crimp orthogonal woven glass/epoxy composites from cluster analysis point of view. These clusters are based on different parameters of peak amplitude, peak frequency, and RA value (rise time divided by peak amplitude). From their investigation, cluster 1 (low frequency, low amplitude events) and 2 (moderate frequency, low amplitude) is correlated to matrix cracking, cluster 3 (low to moderate frequency with high amplitude) with fibre and matrix de-bonding, and cluster 4 (high frequency) with delamination and fibre breakage. Lomov et al. [16] investigated AE response in 3D non-crimp orthogonal woven carbon/epoxy composites undergone damage.

However, identifying cracking in the matrix or fibre in addition to delamination need to be investigated further if AE is to be used as an inspection tool in SHM of 3D woven composites. Hence, the present study (qualitative and quantitative) of 3D angle-interlock woven composite damages using $\mathrm{AE}$ piezoelectric sensors is undertaken. As these structural woven fabrics are attracting the attention of the aerospace industry, the monitoring of initiation and progression of transverse matrix cracking is of considerable interest and importance, since they can lead to delamination and fibre breakage, which result to ultimate failure.

TABLE II: FREQUENCY DISTRIBUTION ACCORDING TO THE DAMAGE MECHANISMS IN COMPOSITE MATERIALS.

\begin{tabular}{|c|c|c|c|c|}
\hline Ref. & $\begin{array}{c}\text { Matrix } \\
\text { cracking }\end{array}$ & $\begin{array}{c}\text { Interface decohesion } \\
\text { (fibre/matrix) }\end{array}$ & $\begin{array}{c}\text { Fibre/matrix friction and } \\
\text { fibres pull-out }\end{array}$ & $\begin{array}{c}\text { Fibres } \\
\text { breakage }\end{array}$ \\
\hline$[17]$ & $50-150 \mathrm{kHz}$ & -- & -- & $140-180 \mathrm{kHz}$ \\
\hline$[18]$ & $30-150 \mathrm{kHz}$ & $30-100 \mathrm{kHz}$ & $180-290 \mathrm{kHz}$ & $300-400 \mathrm{kHz}$ \\
\hline$[19]$ & $80-130 \mathrm{kHz}$ & -- & $250-410 \mathrm{kHz}$ & $250-410 \mathrm{kHz}$ \\
\hline$[13]$ & $\sim 300 \mathrm{kHz}$ & -- & $300 \mathrm{kHz}$ & $>500 \mathrm{kHz}$ \\
\hline$[20]$ & $50-180 \mathrm{kHz}$ & $220-300 \mathrm{kHz}$ & $180-220 \mathrm{kHz}$ & $>300 \mathrm{kHz}$ \\
\hline$[21]$ & $90-110 \mathrm{kHz}$ & -- & $200-300 \mathrm{kHz}$ & $>420 \mathrm{kHz}$ \\
\hline$[22]$ & $<50 \mathrm{kHz}$ & $200-300 \mathrm{kHz}$ & $500-600 \mathrm{kHz}$ & $400-500 \mathrm{kHz}$ \\
\hline$[23]$ & $\sim 140 \mathrm{kHz}$ & $\sim 300 \mathrm{kHz}$ & -- & $\sim 405 \mathrm{kHz}$ \\
\hline$[24]$ & $200-600 \mathrm{kHz}$ & $200-350 \mathrm{kHz}$ & $0.7-1.1 \mathrm{MHz}$ & $>1.5 \mathrm{MHz}$ \\
\hline$[14]$ & $50-80 \mathrm{kHz}$ & $50-150 \mathrm{kHz}$ & -- & $150-500 \mathrm{kHz}$ \\
\hline
\end{tabular}




\section{MATERIALS PRESENTATIONS AND EXPERIMENTAL SET-UP}

In this study, a 3D angle interlock (AI) S2 glass woven composite plate with through-thickness binding was infused using bi-functional epoxy resin (LY564) and hardener (XB3486) supplied by Huntsman. In the AI configuration, the binder goes all the way through-the-thickness and then returns back. According to the binding pattern, shown in Figure 2, one binder yarn is inserted after every three layers of weft (yarn). This structure consists of 4 layers of warp (fibres parallel to weaving direction or at $0^{\circ}$ ) and 3 layers of weft (fibres transverse to weaving direction or at $90^{\circ}$ ), which are held together by the binders (through-thickness fibres) inserted in the weft direction at regular intervals as described in Figure 2.
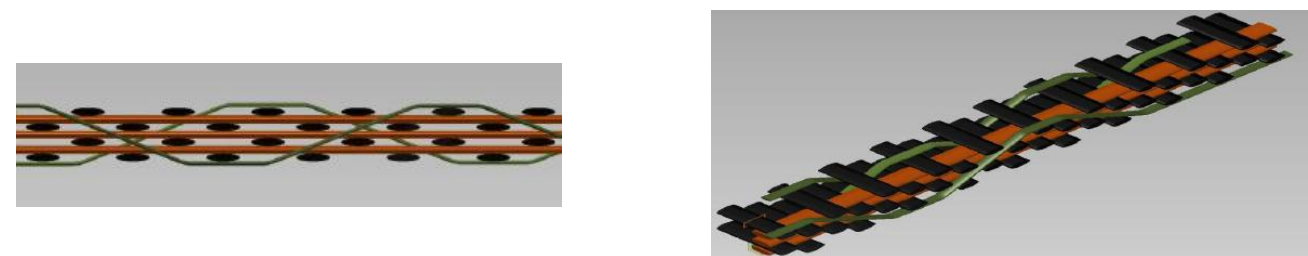

Figure 2: 3D Angle Interlock Woven Composite (front and perspective view) (orange: weft; black: warp; green: binder yarn) (Binder yarn goes all the way through-the-thickness and then returns back).

Tensile testing was carried out according to ASTM standard D3039, on specimens $250 \mathrm{~mm}$ long and $25 \mathrm{~mm}$ wide. The tensile load was applied in the weft direction. A non-contact video extensometer was used to measure the strain developed while the specimen was loaded in an Instron 5982 R2680 testing machine. Three piezoelectric wafer active sensors (PWAS) bonded on the specimen were acting as AE receivers, Figure 3. To develop only transverse cracks, the specimen was loaded up to $20 \%$ of its ultimate strength $\left(\sigma_{\mathrm{f}}\right)$. During loading, acoustic emission signals were recorded and the PWAS were able to pick up AE signal of good strength at a frequency range 100-700 $\mathrm{kHz}$. The acquisition of the signals was performed using software 'AEWin' from Mistras with a sampling rate of $10 \mathrm{MHz}$ and $20 \mathrm{~dB}$ pre-amplification. The AE PWAS sensors used in this study were provided by Steminc, further details in [25].

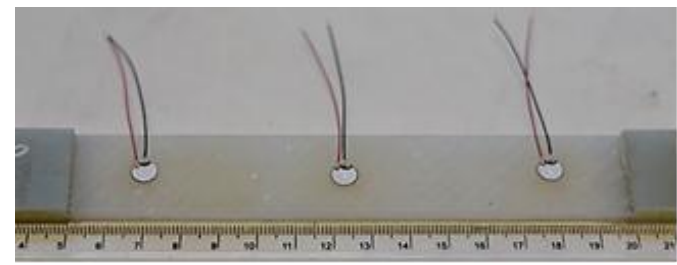

Figure 3: (a) PWAS bonded on a 3D angle interlock glass fibre tensile specimen for acoustic emission.

\section{ANGLE INTERLOCK CRACKING SIMULATION}

In the analysis, the 3D Angle Interlock Woven Composite (3DAWC) (Figure 2) is modelled as a (0/90) cross-ply laminate since the crimp mostly occurs at the interlacement points between the weft and binder yarns. In order to check the effect of this simplification on the in-plane properties of the 3DAWC, analytical homogenization technique "orientation averaging model" is used to calculate approximately the elastic material properties [26] and compare it with the experimental data obtained. As shown in Table III, good agreement between the experimental and 
analytical model is obtained while the last column represents the difference between the calculated values with and without the binder yarns. A larger impact of the through-thethickness reinforcement is expected on the interlaminar fracture toughness rather than inplane stiffness properties. An almost $14 \%$ increase in $\mathrm{E}_{33}$ modulus is predicted when the binder yarns are considered in the analysis.

TABLE III: ELASTIC MATERIAL PROPERTIES OF 3DAWC

\begin{tabular}{|c|c|c|c|c|}
\hline & Experiment & With Binder & Without Binder & Difference (\%) \\
\hline$E_{1}$ & $18.52 \pm 0.87$ & 17.85 & 17.33 & 2.91 \\
\hline$E_{2}$ & $24.83 \pm 1.51$ & 24.00 & 23.48 & 2.16 \\
\hline$E_{3}$ & -- & 12.74 & 11.00 & 13.65 \\
\hline$G_{12}$ & -- & 5.18 & 4.95 & 4.50 \\
\hline$V_{12}$ & -- & 0.31 & 0.32 & 0.68 \\
\hline $\mathrm{V}_{\mathrm{F}}(\%)$ & $V_{F}=50.35 \pm 0.26 ; V_{F}($ warp $)=31.21 \pm 0.26 ; V_{F}$ (weft) $=15.38 \pm 0.36 ; V_{F}($ binder $)=3.05 \pm 0.33$ \\
\hline
\end{tabular}

To determine which constituent part of the 3D woven will experience cracking in the case of uniaxial tension, strain energy density components are calculated for the 3DAWC unit cell when applying $1 \%$ strain along the weft direction. The finite element model is run using the COMSOL Multi-physics software package.

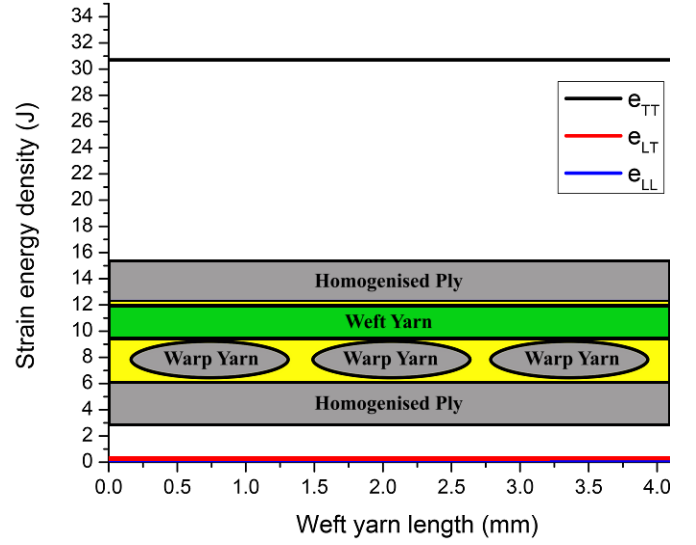

(a)

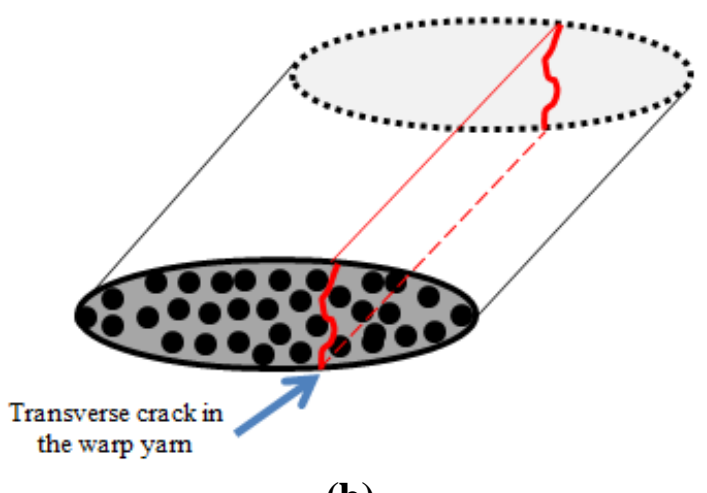

(b)

Figure 4: (a) Strain energy release rate along weft yarn (TT: Transverse component; LT: shear component; LL: axial component); (b) crack on a warp yarn cross section (Transverse crack).

Figure 4 shows that the transverse component $e_{T T}$ of the strain energy density is the highest when compared to the longitudinal $e_{L L}$ and shear $e_{L T}$ components. This implies that the strain energy release rate for the transverse component is the one that leads to matrix cracking in the weft yarn under this loading condition. In addition, having a constant energy release rate along the whole yarn length, it suggests that there is no preferable location within the yarn for the crack to start from. This also means that once a crack is initiated in the yarn, it grows instantaneously through the thickness and along the whole yarn length.

\section{RESULTS AND DISCUSSIONS}

As mentioned in the previous section, at this applied load only transverse cracking occurs in the studied specimen. Figure 5 shows typical AE waveforms received by the 
PWAS\#1, \#2, and \#3, and the associated Fourier transform. In this particular example, the transverse crack occurs closer to PWAS\#2 than the other sensors. This signal looks sharper and stronger than those obtained by PWAS\#1 and \#3. Masmoudi et al. [11] classified this very energetic signals with amplitude above $94 \mathrm{~dB}$ to fibre breaking. However, in our case no fibre breakage occurs, only the transverse crack in the warp yarn, which develops as previously simulated. The amplitudes of this particular events are 96, 98, $81 \mathrm{~dB}$ for PWAS\#1, \#2, and \#3, respectively. The amplitude decreases with the travel length due to the high damping coefficient in this 3DAI composite materials.

Moreover, the frequency components of these signals show clearly two major components, the first one between 100 to $200 \mathrm{kHz}$ and the second one between 250 and $400 \mathrm{kHz}$ for PWAS\#1 and \#3. Moreover, a third component is present between 400 to $600 \mathrm{kHz}$ for PWAS\#2.
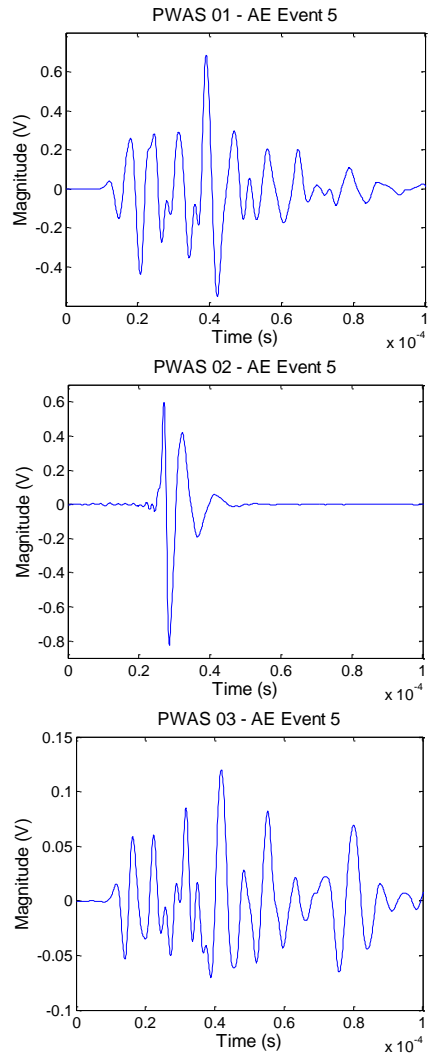

(a)

(c)

(e)
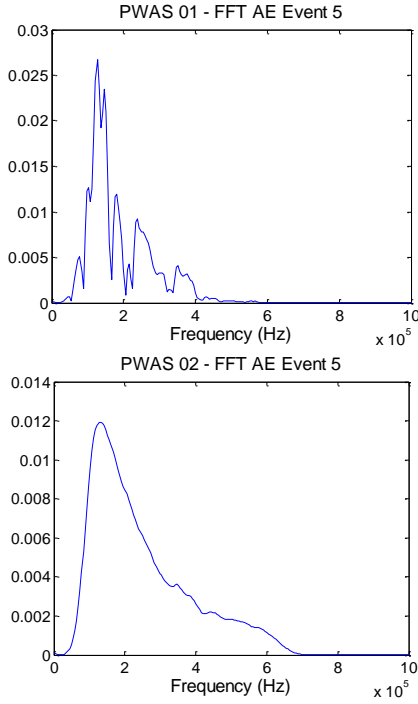

(d)

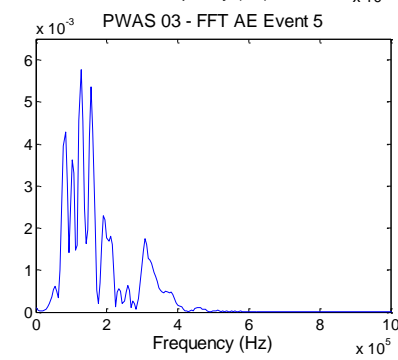

(b)

Figure 5: Typical AE waveforms and Fourier Transform from a transverse crack in 3DAI recorded from (a, b) PWAS\#1; (c, d) PWAS\#2; (e, f) PWAS\#3.

The high frequency and the low frequency component correspond to the wave's extensional mode $S_{0}$ and to the flexural mode $A_{0}$, respectively [27]. This flexural mode has higher amplitude than the extensional mode. It seems that the transverse cracks generate more flexural motion than extensional motion. This presence of a flexural mode would indicate that the crack does not develop symmetrically about the mid-plane of the 3D AI laminate. The crack initiation for the loading in weft direction occurs in the range of applied strain $0.07 \ldots 0.1 \%$ (Figure 6 , showing the data for weft direction loading), a relatively very low level of strain. The amplitude for each AE events (i.e. transverse crack) is between 60 to $100 \mathrm{~dB}$. The signals with lower amplitude were assimilated into noise. 

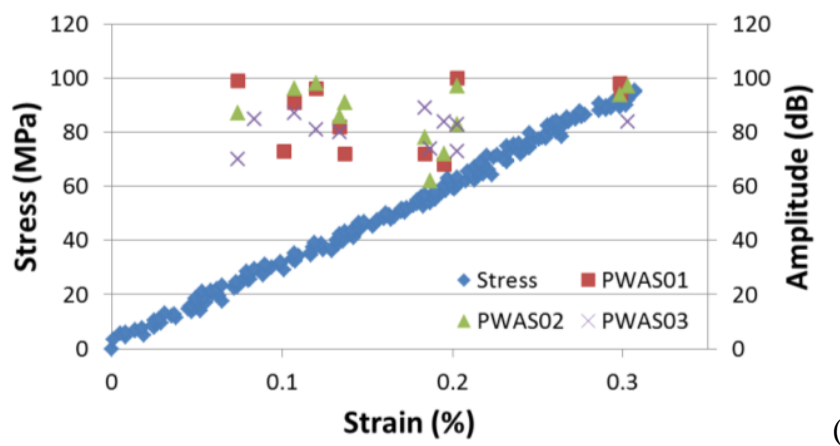

Figure 6: (a) stress-strain curve and the amplitude for each PWAS for each AE events; (c) image illustrating developed transverse cracks.

\section{CONCLUDING REMARKS}

Transverse crack in the warp yarn was detected and quantified in a 3D angle interlock woven glass composite plate during a tensile test using piezoelectric wafer active sensors bonded on the surface of the sample. Our preliminary results show that the amplitude of the AE signal depends on the distance between the crack and the sensor (affected by damping). A complete study on the guided wave propagation and the attenuation effect has to be done in order to increase the accuracy of the results. Moreover, for our materials the amplitude of the AE signal form this transverse crack is between 60 and $100 \mathrm{~dB}$. The frequency component with the highest amplitude is between 100 to $200 \mathrm{kHz}$.

Although some good progress has been demonstrated, there are still some outstanding questions which need to be answered. A complete experimental research program and a finite element method need to be performed in order to better understand the damage evolution (that includes delamination, fibre breakage) and ultimate failure of these 3D AI glass composite plates.

\section{REFERENCES}

1. Gresil, M. and V. Giurgiutiu, Prediction of attenuated guided waves propagation in carbon fiber composites using Rayleigh damping model. Journal of Intelligent Material Systems and Structures, 2014.

2. Mullin, J., J.M. Berry, and A. Gatti, Some Fundamental Fracture Mechanisms Applicable to Advanced Filament Reinforced Composites. Journal of Composite Materials, 1968. 2(1): p. 82103.

3. Mehan, R.L. and J.V. Mullin, Analysis of Composite Failure Mechanisms Using Acoustic Emissions. Journal of Composite Materials, 1971. 5(2): p. 266-269.

4. Godin, N., S. Huguet, and R. Gaertner, Integration of the Kohonen's self-organising map and $k$-means algorithm for the segmentation of the AE data collected during tensile tests on crossply composites. NDT \& E International, 2005. 38(4): p. 299-309.

5. Wadim, J.R., Acoustic emission Applications, ed. D. Endevco. 1978, SAn Juan Capistrano, CA.

6. Chen, O., et al., Acoustic emission characterization of a glass-matrix composite. Nondestructive Testing and Evaluation, 1992. 8-9(1-6): p. 869-878.

7. Ceysson, O., M. Salvia, and L. Vincent, Damage mechanisms characterisation of carbon fibrelepoxy composite laminates by both electrical resistance measurements and acoustic emission analysis. Scripta Materialia, 1996. 34(8): p. 1273-1280.

8. Kim, S.-T. and Y.-T. Lee, Characteristics of damage and fracture process of carbon fiber reinforced plastic under loading-unloading test by using AE method. Materials Science and Engineering: A, 1997. 234-236(0): p. 322-326. 
9. Kotsikos, G., et al., Use of acoustic emission to characterize corrosion fatigue damage accumulation in glass fiber reinforced polyester laminates. Polymer Composites, 1999. 20(5): p. 689-696.

10. Gong, X.L., A. Laksimi, and M.L. Benzeggagh, Nouvelle approche de l'émission acoustique et son application à l'identification des mécanismes d'endommagement dans les matériaux composites. Revue des composites et des matériaux avancés, 1998. 8(1): p. 179-205.

11. Masmoudi, S., A. El Mahi, and R. El Guerjouma, Mechanical behaviour and health monitoring by acoustic emission of sandwich composite integrated by piezoelectric implant. Composites Part B: Engineering, 2014. 67(0): p. 76-83.

12. Barré, S. and M.L. Benzeggagh, On the use of acoustic emission to investigate damage mechanisms in glass-fibre-reinforced polypropylene. Composites Science and Technology, 1994. 52(3): p. 369-376.

13. Komai, K., K. Minoshima, and T. Shibutani, Investigations of the Fracture Mechanism of Carbon/Epoxy Composites by AE Signal Analyses. JSME international journal. Ser. 1, Solid mechanics, strength of materials, 1991. 34(3): p. 381-388.

14. Li, L., et al., Cluster analysis of acoustic emission signals for $2 D$ and $3 D$ woven glass/epoxy composites. Composite Structures, 2014. 116(0): p. 286-299.

15. Liu, P.F., et al., A study on the failure mechanisms of carbon fiberlepoxy composite laminates using acoustic emission. Materials \& Design, 2012. 37(0): p. 228-235.

16. Lomov, S., et al., Monitoring of acoustic emission damage during tensile loading of $3 D$ woven carbon/epoxy composites. Textile Research Journal, 2014. 84(13): p. 1373-1384.

17. Russel, S.S. and E.G. Henneke, Signature analysis of acoustic emission from graphitelepoxy composites. 1977, Interim report, NASA Grant NSG 1238, Report No. VPI-E-77-22.

18. Suzuki, M., et al., Fatigue Fracture Mechanism of Class A-SMC by Acoustic Emission Method. Journal of the Society of Materials Science, Japan, 1987. 36(411): p. 1402-1408.

19. Suzuki, M., et al. Effects of fiber content on fracture mechanisms of short fiber reinforced PET composites. in Proc. 8th Int. Conf. on Composite Materials. 1991.

20. De Groot, P.J., P.A.M. Wijnen, and R.B.F. Janssen, Real-time frequency determination of acoustic emission for different fracture mechanisms in carbon/epoxy composites. Composites Science and Technology, 1995. 55(4): p. 405-412.

21. Ramirez-Jimenez, C.R., et al., Identification of failure modes in glass/polypropylene composites by means of the primary frequency content of the acoustic emission event. Composites Science and Technology, 2004. 64(12): p. 1819-1827.

22. Gutkin, R., et al., On acoustic emission for failure investigation in CFRP: Pattern recognition and peak frequency analyses. Mechanical Systems and Signal Processing, 2011. 25(4): p. 1393-1407.

23. Bussiba, A., et al., Damage evolution and fracture events sequence in various composites by acoustic emission technique. Composites Science and Technology, 2008. 68(5): p. 1144-1155.

24. Jong, H.-J., Transverse Cracking in a Cross-ply Composite Laminate - Detection in Acoustic Emission and Source Characterization. Journal of Composite Materials, 2006. 40(1): p. 37-69.

25. Gresil, M., et al., Predictive modeling of electromechanical impedance spectroscopy for composite materials. Structural Health Monitoring, 2012. 11(6): p. 671-683.

26. Cox, B.N. and M.S. Dadkhah, The Macroscopic Elasticity of 3D Woven Composites. Journal of Composite Materials, 1995. 29(6): p. 785-819.

27. Gresil, M., et al., Predictive model of fatigue crack detection in thick bridge steel structures with piezoelectric wafer active sensors. Smart Structures and Systems, 2013. 12(2): p. 001-635. 


\section{DEStech Publications, Inc.}

\section{CONTRIBUTING AUTHOR COPYRIGHT RELEASE FORM}

As author of the chapter/contribution titled "Acoustic Emission of 3D Angle Interlock Glass Fibre Composites", to appear in the Proceedings of Structural Health Monitoring 2015, I hereby agree to the following:

1. To grant to DEStech Publications, Inc., 439 North Duke Street, Lancaster, PA, 17602, copyright of the above named chapter/contribution (for U.S.

Government employees to the extent transferable), in print, electronic, and online formats. However, the undersigned reserve the following:

a. All proprietary rights other than copyright, such as patent rights.

b. The right to use all or part of this article in future works.

DEStech Publications thereby retains full and exclusive right to publish, market, and sell this material in any and all editions, in the English language or otherwise.

1 I warrant to DEStech Publications, Inc., that I am the (an) author of the above-named chapter/contribution and that I am the (a) copyright holder of the above-named chapter/contribution granted to DEStech Publications, Inc.

2 I warrant that, where necessary and required, I have obtained written permission for the use of any and all copyrighted materials used in the abovenamed chapter/contribution. I understand that I am responsible for all costs of gaining written permission for use of copyrighted materials.

3 I agree to assume full liability to DEStech Publications, Inc. and its licensee, and to hold DEStech Publications, Inc. harmless for any claim or suit filed against DEStech Publications, Inc. for violation of copyrighted material used in the abovenamed contribution.

Please sign and date this form and retain a copy for your records. Please include original form with your chapter/paper.

Thank you for your cooperation.

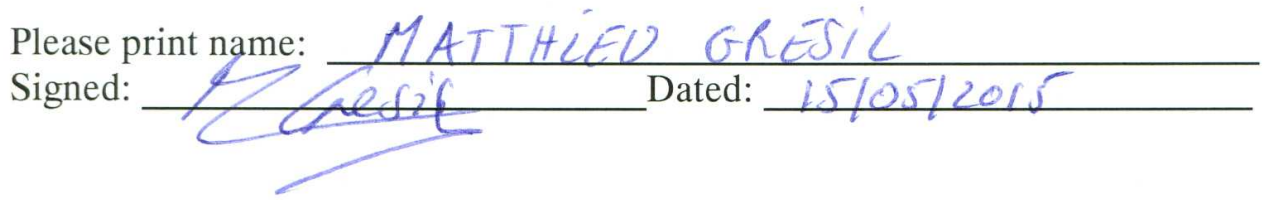

439 NORTH DUKE STREET • LANCASTER, PENNSYLVANIA 17602-4967, U.S.A. Toll Free: (866) 401-4337 • Tel: (717) 290-1660 • Fax: (717) 509-6100 E-mail: info@destechpub.com • Internet address: www.destechpub.com 